\title{
High-Performance Liquid Chromatography Determination of Meloxicam and Piroxicam with Ultraviolet Detection
}

\author{
Sherry Cox, ${ }^{1}$ Joan Hayes, ${ }^{1}$ Jason Yarbrough, ${ }^{1}$ Tamara Veiga-Parga, ${ }^{1}$ and Cheryl Greenacre ${ }^{2}$ \\ ${ }^{1}$ Department of Biomedical and Diagnostic Sciences, College of Veterinary Medicine, University of Tennessee, 2407 River Drive, \\ Knoxville, TN 37996, USA \\ ${ }^{2}$ Department of Small Animal Clinical Sciences, College of Veterinary Medicine, University of Tennessee, 2407 River Drive, \\ Knoxville, TN 37996, USA
}

Correspondence should be addressed to Sherry Cox; scox6@utk.edu

Received 19 August 2014; Revised 25 September 2014; Accepted 25 September 2014; Published 27 October 2014

Academic Editor: Teresa Kowalska

Copyright (C) 2014 Sherry Cox et al. This is an open access article distributed under the Creative Commons Attribution License, which permits unrestricted use, distribution, and reproduction in any medium, provided the original work is properly cited.

\begin{abstract}
A simple accurate and sensitive high-performance liquid chromatographic method for the determination of meloxicam and piroxicam concentrations in small volume plasma samples has been developed. Following a liquid extraction using chloroform, samples were separated by reversed-phase high-performance liquid chromatography on an XBridge $\mathrm{C}_{18}$ column $(4.6 \times 250 \mathrm{~mm})$ and quantified using ultraviolet detection at $360 \mathrm{~nm}$. The mobile phase was a mixture of water with glacial acetic acid ( $\mathrm{pH} 3.0)$ and acetonitrile $(50: 50)$, with a flow rate of $1.0 \mathrm{~mL} / \mathrm{min}$. The standard curve ranged from 5 to $10,000 \mathrm{ng} / \mathrm{mL}$ for meloxicam in bearded dragon (Pogona vitticeps) plasma and piroxicam in crane (Grus rubicunda) plasma. Intra- and interassay variability for meloxicam and piroxicam were less than $10 \%$ and the average recovery was greater than $90 \%$ for both drugs. This method was developed in bearded dragon and crane plasma and should be applicable to any species, making it useful for those investigators dealing with small sample volumes, particularly when conducting pharmacokinetics studies which require multiple sampling from the same animal.
\end{abstract}

\section{Introduction}

Meloxicam, 4-hydroxy-2-methyl-N-(5-methyl-1,3-thiazol-2yl)-1,1-dioxo-1 $1 \lambda^{6}, 2$-benzothiazine-3-carboxamide, and piroxicam, 4-hydroxy-2-methyl-1,1-dioxo-N-pyridin-2-yl-1 $\lambda^{6}, \quad$ benzothiazine-3-carboxamide, are nonsteroidal anti-inflammatory drugs (NSAIDs) with analgesic properties. They are generally used to treat osteoarthritis and rheumatoid arthritis; however, they can be used for other painful conditions such as injuries, cancer surgery, and dental infections. Meloxicam preferentially inhibits the cyclooxygenase-2 (COX-2) enzyme over COX-1. The ability to only inhibit the inflammatory COX proved to be revolutionary for pain management. The introduction of COX-2 preferential NSAIDs has reduced stomach and intestinal side effects. While piroxicam is used to treat painful conditions, it has recently been used in a variety of protocols to treat squamous cell carcinoma and hemangiosarcoma. Meloxicam can be metabolized to as many as four biologically inactive metabolites depending on the species; however, the 5-hydroxy methyl derivative is the most common metabolite. Piroxicam metabolism occurs via a cytochrome P450 2C isoform to multiple biologically inactive metabolites, with 5-hydroxy-prioxicam being the most common.

Nonsteroidal anti-inflammatory drugs are commonly used in large and small veterinary practices for relief of pain, fever, and inflammation. Increasing public awareness of animal welfare will likely continue to make proper use of NSAIDs a priority in the treatment of all domestic animals for painful inflammatory conditions. Therefore knowledge of the pharmacokinetics of NSAIDs in the specific species of interest will be required to provide for the safe and efficacious use of these drugs.

Meloxicam and piroxicam levels have been determined using a number of analytical methods [1-19]. Although mass spectrometry $[1,2,10,14]$ can produce the highest detection sensitivity, it may not be readily available in all laboratories and is expensive. The most economical method is highperformance liquid chromatography with ultraviolet detection (HPLC-UV). In order to obtain a suitable limit of 
quantification (LOQ) for the determination of meloxicam and piroxicam in biological samples several different processes have been used. Some of the methods employed include liquid-liquid extractions using diethyl ether $[3,5,7$, $12,16]$ or methylene chloride $[18,19]$, protein precipitation $[4,6,13,17]$, precolumn enrichment $[8,9,15]$, and solid phase extraction [11]. In many of the liquid-liquid extraction methods developed, large amounts of organic solvents are needed. Also, sample volumes for all the extraction methods can be large, many requiring from 0.2 to $1 \mathrm{~mL}$ of sample. Precolumn enrichment can require the expense of precolumns and the need for column switching. The aim of this paper is to describe a simple, sensitive, and accurate method for extracting meloxicam and piroxicam from small volume plasma samples using HPLC.

\section{Material and Methods}

2.1. Instrumentation. The chromatography system consisted of a 2695 separation module and a 2487 ultraviolet detector (Waters, Milford, MA). Separation was achieved on a Waters XBridge $\mathrm{C}_{18}$ column $(4.6 \times 250 \mathrm{~mm}, 5 \mu \mathrm{m})$ preceded by a $5 \mu \mathrm{m}$ XBridge $\mathrm{C}_{18}$ guard column $(3.9 \times 20 \mathrm{~mm})$. The mobile phase was an isocratic mixture of A: $990 \mathrm{~mL}$ water with $10 \mathrm{~mL} 85 \%$ glacial acetic acid, pH 3.0 with $1 \mathrm{~N}$ sodium hydroxide, and B: acetonitrile $(50: 50)$. All solutions were filtered through a $0.22 \mu \mathrm{m}$ filter and degassed before their use. The water was replaced on a daily basis. The flow rate was $1.0 \mathrm{~mL} / \mathrm{min}$, and the column and autosampler temperature were ambient which was $23^{\circ} \mathrm{C}$. The ultraviolet detector was set at a wavelength of $360 \mathrm{~nm}$.

2.2. Reagents. Meloxicam (Figure 1) was purchased from Toronto Research Chemicals (Ontario, Canada) and was 99\% pure. Piroxicam (Figure 1), which was the internal standard (99\% purity), was purchased from US Pharmacopeia (Rockville, MD). All reagent grade chemicals and solvents were purchased from Fisher Scientific (Pittsburg, PA). Water (18.2 megaohms) was obtained from a Barnstead Nanopure Infinity (Dubuque, IA) ultrapure water system.

2.3. Preparation of Calibration Standards. Five milligrams each of meloxicam or piroxicam was weighed using a Sartorius Microbalance (Elk Grove, IL) and dissolved in methanol to produce stock concentrations of $100 \mu \mathrm{g} / \mathrm{mL}$. Dilutions of the meloxicam and piroxicam stock standards were prepared in methanol to produce $0.1,1,5$, and $10 \mu \mathrm{g} / \mathrm{mL}$ working stock solutions. Standards were aliquoted into $2 \mathrm{~mL}$ vials to prevent evaporation and cross contamination. All solutions were protected from light in bottles wrapped in aluminum foil and stored at $-20^{\circ} \mathrm{C}$. By comparing standard areas over time it was determined that solutions were stable for a minimum of 6 months.

For preparation of calibration standards and quality control samples, appropriate volumes of stock solutions were placed in screw top tubes and evaporated with nitrogen gas and then untreated plasma was added. The final concentrations for the calibration standard curve were 5, 10, 25, 50, 100,
Meloxicam<smiles>Cc1cnc(NC(=O)C2=C(O)c3ccccc3S(=O)(=O)N2C)s1</smiles>

Piroxicam<smiles>CN1C(C(=O)Nc2ccccn2)=C(O)c2ccccc2S1(=O)=O</smiles>

FIGURE 1: Structures of meloxicam and piroxicam.

$250,500,800,1000,2500,5000$, and $10,000 \mathrm{ng} / \mathrm{mL}$ with quality control standards of 15, 750, 1250, 3000, and $7500 \mathrm{ng} / \mathrm{mL}$. Calibration standards and control samples were treated the same as test samples. The calibration curve was constructed by using the ratio of the peak area of the analyte divided by the peak area of the internal standard versus the concentration. Linearity was assessed by unweighted linear regression analysis. The calibration curve had a correlation coefficient of 0.99 or better. The acceptance criterion for each backcalculated standard and quality control concentration was $15 \%$ deviation from the nominal value except for lower limit of quantification (LLOQ), which was set at $20 \%$.

2.4. Sample Extraction. Meloxicam or piroxicam was extracted from bearded dragon (Pogona vitticeps), sandhill crane (Grus canadensis), or sow plasma and sow milk using a liquid extraction. Previously frozen plasma or milk samples were thawed, and $100 \mu \mathrm{L}$ was placed into a $7 \mathrm{~mL}$ screw cap tube. Fifteen microliters of piroxicam for meloxicam extraction or meloxicam for piroxicam extraction $(5 \mu \mathrm{g} / \mathrm{mL})$ was added. After the addition of $100 \mu \mathrm{L}$ of $1 \mathrm{M}$ hydrochloride and $2 \mathrm{~mL}$ of chloroform, tubes were vortex-mixed at a high speed for 60 seconds followed by centrifugation for 20 minutes at $1000 \times \mathrm{g}$. The supernatant was removed and placed in a clean $16 \times$ 100 glass test tube and then evaporated with nitrogen. After evaporation, samples were redissolved in $250 \mu \mathrm{L}$ of the mobile phase and vortex-mixed and the supernatant was placed in total recovery chromatographic vials (Waters, Milford, MA) and then $100 \mu \mathrm{L}$ injected into the system.

\section{Results and Discussion}

3.1. Method Development and Optimization. The goal of the study was to develop a simple method that did not require the use of mass spectrometry, column switching, or 
large amounts of organic solvents. We found that ultraviolet detection at $360 \mathrm{~nm}$ produced chromatograms with the largest meloxicam and piroxicam areas compared to those at $350 \mathrm{~nm}, 355 \mathrm{~nm}$, and $364 \mathrm{~nm}$. We also tried the extraction with and without the addition of hydrochloric acid. Without $\mathrm{HCl}$ the average drug recovery was $23 \%$ while the addition of the acid increased recovery to an overall average of $92 \%$.

During method development several organic solutions and mixtures were tested including acetonitrile, methanol, acetonitrile:methanol $(1: 1)$, hexane, ethyl acetate, methylene chloride, and chloroform. With the exception of chloroform the recoveries for the solutions used ranged from 68 to $80 \%$. There was also decreased peak resolution and/or interference from plasma components compared to chloroform. Once chloroform was selected as the extraction solvent the appropriate volume was determined. One milliliter produced a recovery of roughly $75 \%$ for both meloxicam and piroxicam and $3 \mathrm{~mL}$ produced the same recovery as $2 \mathrm{~mL}$ which was the volume selected. We also looked at different methods for mixing the samples and found that vortexing the samples for sixty seconds produced a greater recovery than rocking for twenty minutes.

\subsection{Analytical Method Validation}

3.2.1. Specificity. For specificity testing, untreated crane, bearded dragon, or sow plasma was prepared in the same manner as study samples and no endogenous plasma components from any species interfered with the elution of the compounds of interest. Five different blank plasma samples from adult male and female bearded dragons or cranes were used in the prevalidation process and a blank sample from each animal was included in the analysis. Five different blank plasma samples from adult sows were used in the prevalidation process and a blank sample from each animal was also analyzed. Meloxicam and piroxicam metabolites are biologically inactive so no effort was made to analyze these compounds in any species. Figure 2 illustrates chromatograms of a (a) blank bearded dragon sample, (b) a $250 \mathrm{ng} / \mathrm{mL}$ spiked plasma standard, (c) a plasma sample from a bearded dragon after intramuscular administration of $0.4 \mathrm{mg} / \mathrm{kg}$ meloxicam, (d) a blank sandhill crane sample, (e) an $800 \mathrm{ng} / \mathrm{mL}$ spiked plasma standard, (f) a plasma sample from a sandhill crane after oral administration of $0.5 \mathrm{mg} / \mathrm{kg}$ piroxicam, (g) a blank sow milk sample, (h) a $250 \mathrm{ng} / \mathrm{mL}$ spiked milk standard, and (i) a milk sample from a sow after intramuscular administration with $0.8 \mathrm{mg} / \mathrm{kg}$ meloxicam. The retention times in both bearded dragon and sandhill crane plasma were 7.3 and 5.9 minutes for meloxicam and piroxicam, respectively. The retention times in milk were 7.6 and 5.9 minutes.

For milk specificity testing, untreated sow milk was prepared in the same manner as study samples and no endogenous milk components interfered with the elution of the compounds of interest. Five different blank milk samples from adult sows were used in the prevalidation process and a blank sample from each animal was also analyzed.
3.2.2. Linearity, Accuracy, and Precision. The plasma peak ratio (area of meloxicam or piroxicam divided by the internal standard area) was plotted and produced a linear curve for the concentration range used $(5-10,000 \mathrm{ng} / \mathrm{mL})$ for each drug with a correlation coefficient of 0.995 to 0.999 . The mean slope, intercept, and $r^{2}$ values are reported in Tables 1, 2, and 3 . Intra- and inter-day assay relative standard deviation (RSD) for plasma spiked with specific concentrations of meloxicam or piroxicam were used to determine accuracy and precision which ranged from $1.1 \%$ to $11.3 \%$. The precision was found to be below the set $\pm 15 \%$ for all quality control samples. The use of an internal standard corrects for the intra- and interday assay variability in the assay.

3.2.3. Recovery and Limit of Quantification (LLOQ). The recovery (Tables 4,5 , and 6 ) of meloxicam and piroxicam from spiked plasma and milk was determined by comparing areas of extracted plasma or milk samples to those of directly injected analytes without undergoing extraction at concentrations of $15,750,1250,3000$, and $7500 \mathrm{ng} / \mathrm{mL}$. The average plasma recovery ranged from $91 \%$ to $97 \%$ for meloxicam and from $88 \%$ to $94 \%$ for piroxicam. The average recovery from milk ranged from $88 \%$ to $95 \%$ for meloxicam. The lower limit of quantification (LLOQ) was $5 \mathrm{ng} / \mathrm{mL}$ for both drugs in both plasma and milk matrix, which represents a peak approximately five times the baseline noise. The LLOQ is more than adequate for use in pharmacokinetic studies. If a lower LLOQ is needed sample size could be increased.

3.2.4. Stability. Testing of the short term stability of the quality control standards for both milk and plasma indicated there was less than a $1 \%$ loss of either drug after 24 hours in the autosampler and a 1\% loss of both drugs after 24 hours in the refrigerator at $4^{\circ} \mathrm{C}$. Therefore, if there was power or equipment failure samples could be reanalyzed. Samples in our studies were stored at $-80^{\circ} \mathrm{C}$, thawed one time, and analyzed; however, there was no loss of drug after 2 freezethaw cycles. There was also no loss of drug after two weeks of storage at $-80^{\circ} \mathrm{C}$ which is one week longer than study samples were stored for analysis.

\subsection{Application of Method}

3.3.1. Method Application. Figure 3 is a representative concentration-time profile from a meloxicam pharmacokinetic study conducted in bearded dragons (Pogona vitticeps) after receiving a $0.4 \mathrm{mg} / \mathrm{kg}$ intramuscular dose of meloxicam. The $T_{\max }, C_{\max }$, and half-life for this animal were $0.75 \mathrm{~h}$, $3953 \mathrm{ng} / \mathrm{mL}$, and $4.9 \mathrm{~h}$, respectively. Figure 4 is a representative concentration-time profile from a piroxicam pharmacokinetic study conducted in sandhill cranes (Grus canadensis) after receiving a $0.5 \mathrm{mg} / \mathrm{kg}$ oral dose of piroxicam. The $T_{\max }, C_{\max }$, and half-life for this animal were $1 \mathrm{~h}, 4840 \mathrm{ng} / \mathrm{mL}$, and $73 \mathrm{~h}$, respectively. 


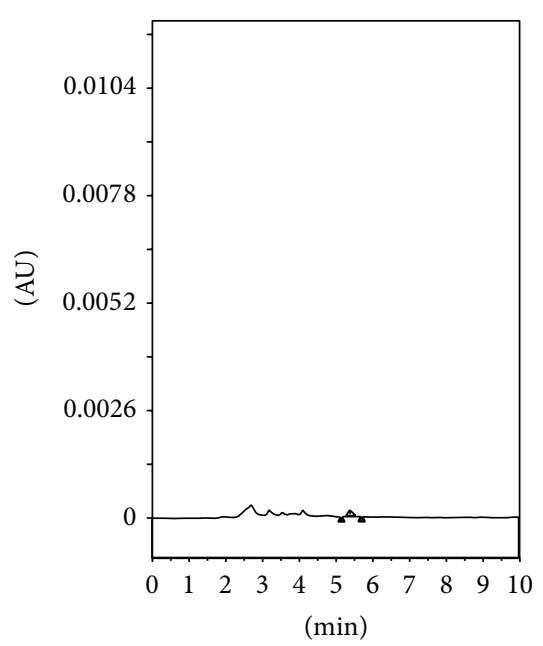

(a)

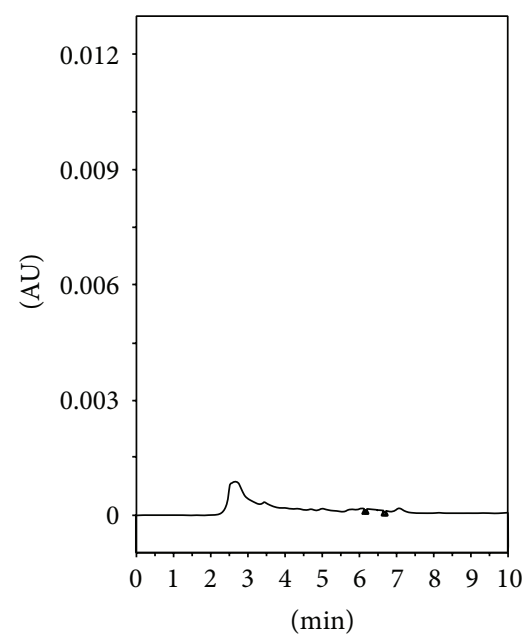

(d)

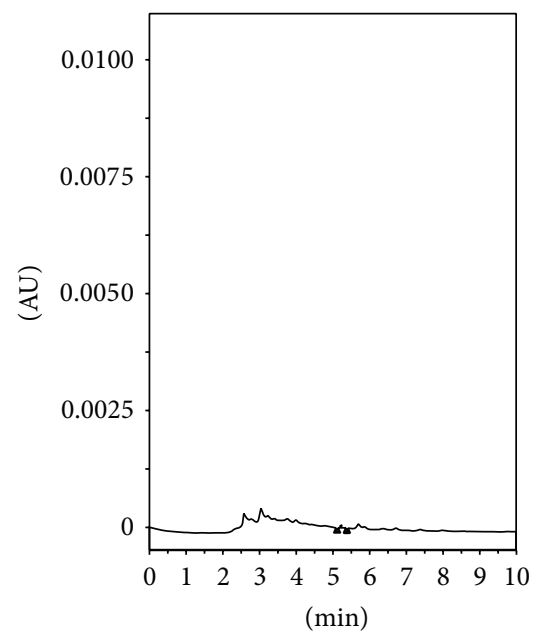

(g)

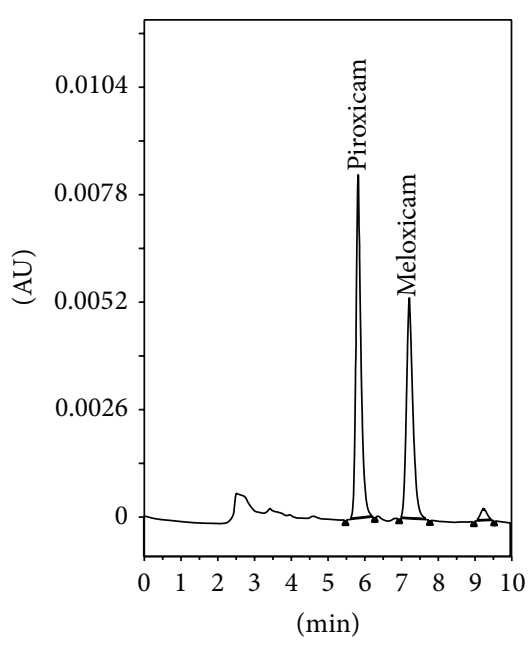

(b)

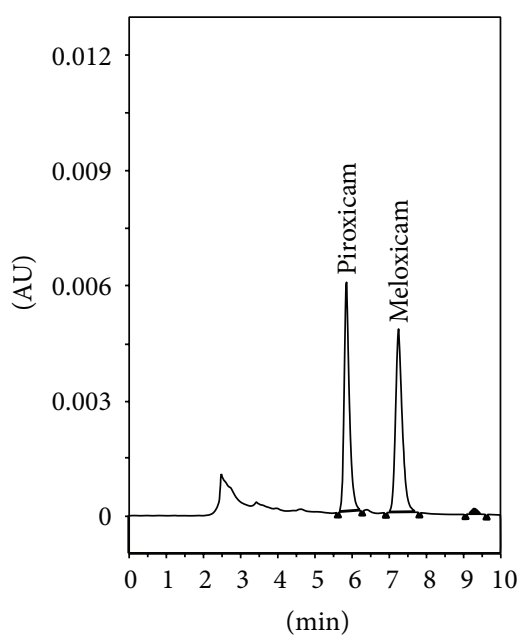

(e)

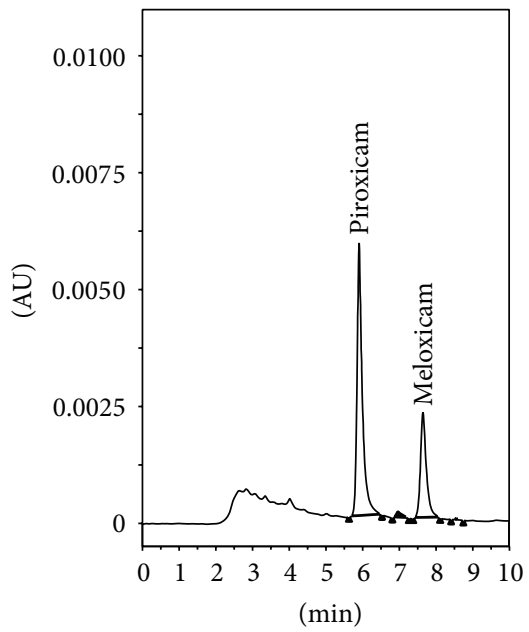

(h)

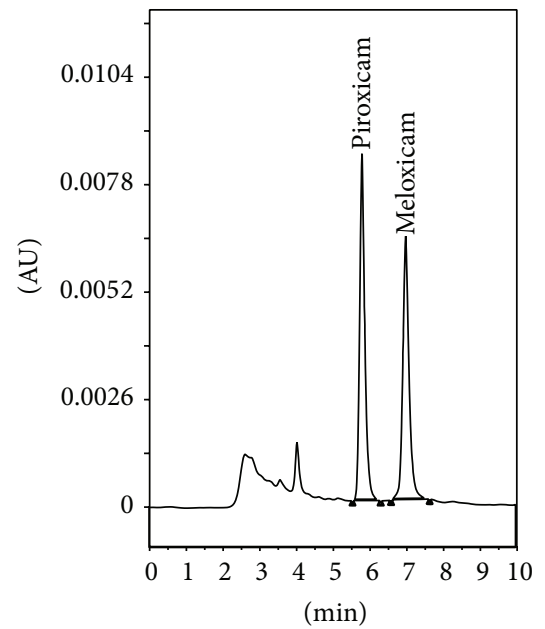

(c)

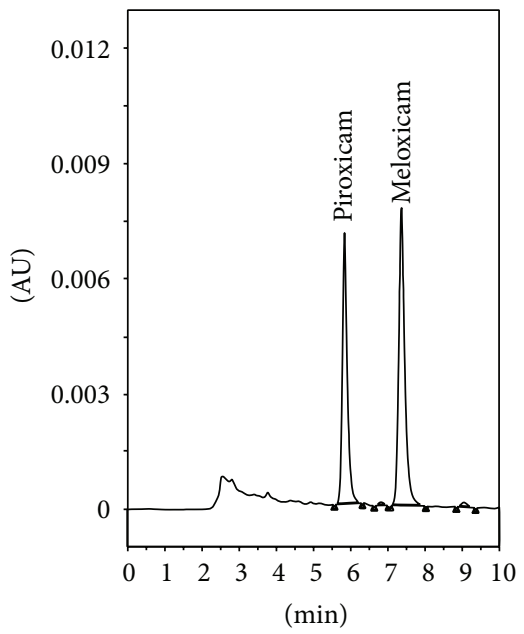

(f)

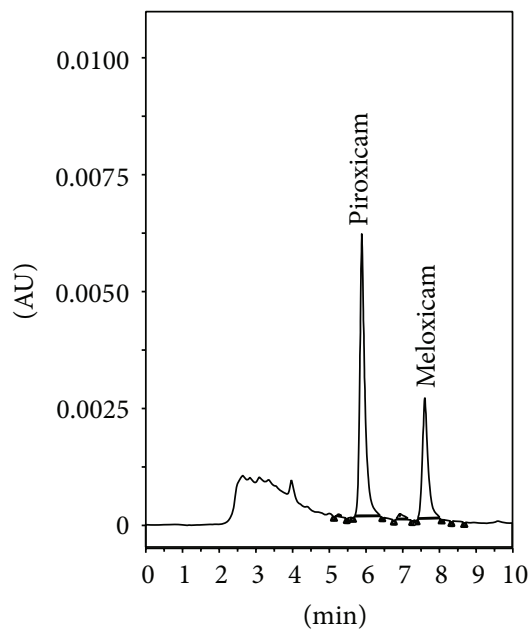

(i)

Figure 2: Chromatograms for meloxicam and piroxicam. (a) Blank bearded dragon plasma sample, (b) a $250 \mathrm{ng} / \mathrm{mL}$ spiked plasma standard, (c) a plasma sample from a bearded dragon after intramuscular administration of $0.4 \mathrm{mg} / \mathrm{kg}$ meloxicam, (d) a blank sandhill crane plasma sample, (e) an $800 \mathrm{ng} / \mathrm{mL}$ spiked plasma standard, (f) a plasma sample from a sandhill crane after oral administration of $0.5 \mathrm{mg} / \mathrm{kg}$ piroxicam, (g) a blank sow milk sample, (h) a $250 \mathrm{ng} / \mathrm{mL}$ spiked milk standard, and (i) a milk sample from a sow dosed with $0.8 \mathrm{mg} / \mathrm{kg}$ meloxicam. 
TABLE 1: Intra-assay accuracy, precision and assay linearity for meloxicam in plasma.

\begin{tabular}{|c|c|c|c|c|}
\hline \multicolumn{5}{|c|}{ Intra-assay variability $(n=5)$} \\
\hline $\begin{array}{l}\text { Concentration added } \\
(\mathrm{ng} / \mathrm{mL})\end{array}$ & $\begin{array}{c}\text { Concentration measured } \\
\text { (ng/mL) bearded dragon } \\
\text { (Mean } \pm \text { S.D. })\end{array}$ & R.S.D. (\%) & $\begin{array}{l}\text { Concentration measured } \\
(\mathrm{ng} / \mathrm{mL}) \text { pig }(\text { Mean } \pm \text { S.D. })\end{array}$ & R.S.D. (\%) \\
\hline 15 & $15 \pm 0.71$ & 4.6 & $15 \pm 0.21$ & 1.4 \\
\hline 750 & $708 \pm 28$ & 4.0 & $757 \pm 69$ & 9.1 \\
\hline 1250 & $1156 \pm 46$ & 4.0 & $1149 \pm 2.8$ & 0.25 \\
\hline 3000 & $2982 \pm 155$ & 5.1 & $2990 \pm 160$ & 5.3 \\
\hline 7500 & $7528 \pm 758$ & 10.0 & $7300 \pm 680$ & 9.3 \\
\hline \multicolumn{5}{|c|}{ Assay linearity $(n=5)$} \\
\hline & Mean \pm S.D. & R.S.D. (\%) & Mean \pm S.D. & R.S.D. (\%) \\
\hline$Y$-Intercept & $0.0037 \pm 0.0004$ & 11.3 & $0.0033 \pm 0.0003$ & 9.1 \\
\hline Slope & $0.0020 \pm 0.0002$ & 12.3 & $0.0021 \pm 0.0002$ & 9.5 \\
\hline$r^{2}$ & $0.995 \pm 0.0028$ & 0.28 & $0.994 \pm 0.0038$ & 0.38 \\
\hline
\end{tabular}

S.D.: standard deviation; $n$ : number of samples; RSD: relative standard deviation.

TABLE 2: Intra-assay accuracy, precision and assay linearity for piroxicam in plasma.

\begin{tabular}{lcc}
\hline $\begin{array}{l}\text { Concentration added } \\
(\mathrm{ng} / \mathrm{mL})\end{array}$ & $\begin{array}{c}\text { Intra-assay variability }(n=5) \\
\text { Concentration measured } \\
(\mathrm{ng} / \mathrm{mL})(\text { Mean } \pm \text { S.D. })\end{array}$ & $\begin{array}{c}\text { R.S.D. }(\%) \\
15\end{array}$ \\
750 & $21 \pm 0.41$ & 3.0 \\
1250 & $1293 \pm 44$ & 3.4 \\
3000 & $3006 \pm 69$ & 2.0 \\
7500 & $7517 \pm 399$ & 5.0 \\
\hline & Assay linearity $(n=5)$ & R.S.D. (\%) \\
\hline$Y$-Intercept & Mean \pm S.D. & 3.44 \\
Slope & $-0.0106 \pm 0.0004$ & 1.51 \\
$r^{2}$ & $0.0012 \pm 0.000018$ & 0.28 \\
\hline
\end{tabular}

S.D.: standard deviation; $n$ : number of samples; RSD: relative standard deviation.

TABLE 3: Intra-assay accuracy, precision and assay linearity for meloxicam in milk.

\begin{tabular}{lcc}
\hline $\begin{array}{l}\text { Concentration added } \\
(\mathrm{ng} / \mathrm{mL})\end{array}$ & $\begin{array}{c}\text { Intra-assay variability }(n=5) \\
\text { Concentration measured } \\
(\mathrm{ng} / \mathrm{mL})(\text { Mean } \pm \text { S.D. })\end{array}$ & R.S.D. (\%) \\
\hline 15 & $15 \pm 0.41$ & 2.7 \\
750 & $727 \pm 27$ & 3.7 \\
1250 & $1149 \pm 30$ & 2.6 \\
3000 & $3000 \pm 69$ & 2.3 \\
7500 & $7450 \pm 399$ & 5.3 \\
\hline & Assay linearity $(n=5)$ & R.S.D. (\%) \\
\hline Y-Intercept & Mean \pm S.D. & 5.06 \\
Slope & $-0.0079 \pm 0.0004$ & 0.76 \\
$r^{2}$ & $0.0017 \pm 0.000013$ & 0.30 \\
\hline
\end{tabular}

S.D.: standard deviation; $n$ : number of samples; RSD: relative standard deviation. 
TABLE 4: Inter-assay variability and recovery for meloxicam in plasma and $(n=5)$.

\begin{tabular}{|c|c|c|c|c|c|c|}
\hline $\begin{array}{l}\text { Concentration added } \\
(\mathrm{ng} / \mathrm{mL})\end{array}$ & $\begin{array}{c}\text { Concentration measured } \\
\text { bearded dragon } \\
(\mathrm{ng} / \mathrm{mL})(\text { Mean } \pm \text { S.D. })\end{array}$ & R.S.D. (\%) & Recovery (\%) & $\begin{array}{l}\text { Concentration measured pig } \\
(\mathrm{ng} / \mathrm{mL})(\text { Mean } \pm \text { S.D. })\end{array}$ & R.S.D. (\%) & Recovery (\%) \\
\hline 15 & $14 \pm 1$ & 7.1 & 97 & $15 \pm 0.4$ & 3.0 & 99 \\
\hline 750 & $743 \pm 15$ & 2.1 & 91 & $746 \pm 12$ & 1.5 & 98 \\
\hline 1250 & $1220 \pm 73$ & 6.0 & 94 & $1227 \pm 21$ & 1.7 & 95 \\
\hline 3000 & $3011 \pm 128$ & 4.3 & 95 & $2970 \pm 32$ & 1.1 & 95 \\
\hline 7500 & $7467 \pm 562$ & 7.5 & 95 & $7466 \pm 330$ & 4.4 & 95 \\
\hline
\end{tabular}

SD: standard deviation; $n$ : number of days; RSD: relative standard deviation.

TABLE 5: Inter-assay variability and recovery for piroxicam in plasma and $(n=5)$.

\begin{tabular}{lccc}
\hline $\begin{array}{l}\text { Concentration added } \\
(\mathrm{ng} / \mathrm{mL})\end{array}$ & $\begin{array}{c}\text { Concentration measured } \\
(\mathrm{ng} / \mathrm{mL})(\text { Mean } \pm \text { S.D. })\end{array}$ & R.S.D. (\%) & Recovery $(\%)$ \\
\hline 15 & $22 \pm 2$ & 9.9 & 88 \\
750 & $746 \pm 56$ & 7.4 & 94 \\
1250 & $1255 \pm 142$ & 11.3 & 88 \\
3000 & $2976 \pm 147$ & 4.9 & 89 \\
7500 & $7500 \pm 419$ & 5.6 & 88 \\
\hline
\end{tabular}

SD: standard deviation; $n$ : number of days; RSD: relative standard deviation.

TABLE 6: Inter-assay variability and recovery for meloxicam in milk $(n=5)$.

\begin{tabular}{lccc}
\hline $\begin{array}{l}\text { Concentration added } \\
(\mathrm{ng} / \mathrm{mL})\end{array}$ & $\begin{array}{c}\text { Concentration measured } \\
(\mathrm{ng} / \mathrm{mL})(\text { Mean } \pm \text { S.D. })\end{array}$ & $\begin{array}{c}\text { R.S.D. } \\
(\%)\end{array}$ & $\begin{array}{c}\text { Recovery } \\
(\%)\end{array}$ \\
\hline 15 & $17 \pm 2$ & 10.8 & 94 \\
750 & $730 \pm 68$ & 9.2 & 91 \\
1250 & $1233 \pm 78$ & 6.3 & 90 \\
3000 & $2976 \pm 131$ & 4.4 & 95 \\
7500 & $7500 \pm 330$ & 4.4 & 88 \\
\hline
\end{tabular}

SD: standard deviation; $n$ : number of days; RSD: relative standard deviation.

\section{Conclusion}

In conclusion, this HPLC method quantifies meloxicam or piroxicam from plasma by combining a liquid extraction procedure with ultraviolet detection. This analytical procedure was authenticated in terms of recovery, linearity, LLOQ, precision, and accuracy. The limit of quantification and recovery are more than adequate for use in pharmacokinetic studies. The results of this study indicate that this HPLC procedure is a reproducible method that provides consistent quantification of meloxicam or piroxicam in plasma from different species.

It is a simple method that eliminates the need for mass spectrometry, column switching, and large volumes of organic solvents. It allows numerous samples to be processed by a single technician. This method has been used successfully to determine meloxicam and piroxicam concentrations in plasma and milk samples at this institution. This method utilizes a small sample size of $100 \mu \mathrm{L}$ making it potentially useful for small dogs, cats, or other small animals. It could

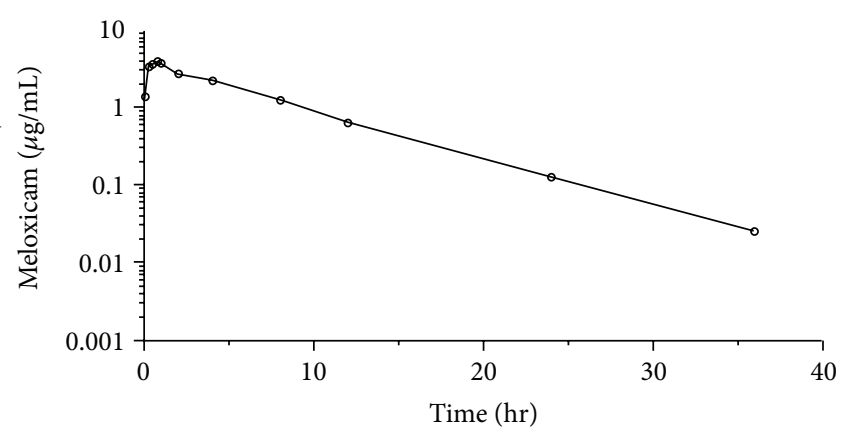

FIGURE 3: Concentration time profile of meloxicam in bearded dragon plasma after a $0.4 \mathrm{mg} / \mathrm{kg}$ intramuscular dose.

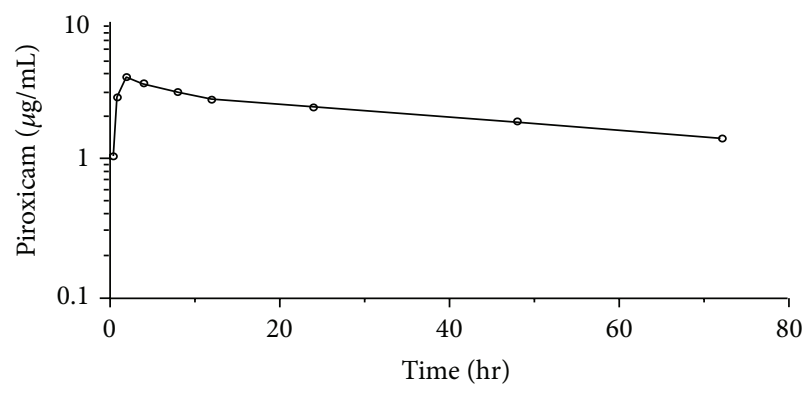

FIGURE 4: Concentration time profile of piroxicam in sandhill crane plasma after a $0.5 \mathrm{mg} / \mathrm{kg}$ oral dose.

be particularly useful to investigators when conducting pharmacokinetic studies in small animals which require multiple sampling from the same animal. 


\section{Conflict of Interests}

The authors declare that there is no conflict of interests regarding the publication of this paper.

\section{References}

[1] A. J. Kreuder, J. F. Coetzee, L. W. Wulf et al., "Bioavailability and pharmacokinetics of oral meloxicam in llamas," $B M C$ Veterinary Research, vol. 8, article 85, 2012.

[2] P. R. Malreddy, J. F. Coetzee, B. Kukanich, and R. Gehring, "Pharmacokinetics and milk secretion of gabapentin and meloxicam co-administered orally in Holstein-Friesian cows," Journal of Veterinary Pharmacology and Therapeutics, vol. 36, no. 1, pp. 14-20, 2013.

[3] J.-W. Bae, C.-I. Choi, C.-G. Jang, and S.-Y. Lee, "Effects of CYP2C $9 * 1 / * 13$ on the pharmacokinetics and pharmacodynamics of meloxicam," British Journal of Clinical Pharmacology, vol. 71, no. 4, pp. 550-555, 2011.

[4] H. Zhang and H.-K. Choi, "Analysis of meloxicam by highperformance liquid chromatography with cloud-point extraction," Analytical and Bioanalytical Chemistry, vol. 392, no. 5, pp. 947-953, 2008.

[5] J.-W. Bae, M.-J. Kim, C.-G. Jang, and S.-Y. Lee, "Determination of meloxicam in human plasma using a HPLC method with UV detection and its application to a pharmacokinetic study," Journal of Chromatography B: Analytical Technologies in the Biomedical and Life Sciences, vol. 859, no. 1, pp. 69-73, 2007.

[6] A. Medvedovici, F. Albu, C. Georgita, C. Mircioiu, and V. David, "A non-extracting procedure for the determination of meloxicam in plasma samples by HPLC-DIODE Array Detection," Arzneimittel-Forschung, vol. 55, no. 6, pp. 326-331, 2005.

[7] H. Blain, C. Boileau, F. Lapicque et al., "Limitation of the in vitro whole blood assay for predicting the COX selectivity of NSAIDs in clinical use," British Journal of Clinical Pharmacology, vol. 53, no. 3, pp. 255-265, 2002.

[8] D. Turck, U. Busch, G. Heinzel, and H. Narjes, "Clinical pharmacokinetics of meloxicam," Arzneimittel Forschung-Drug Research, vol. 47, no. 3, pp. 253-258, 1997.

[9] J. Schmid, U. Busch, G. Heinzel, G. Bozler, S. Kaschke, and M. Kummer, "Pharmacokinetics and metabolic pattern after intravenous infusion and oral administration to healthy subjects," Drug Metabolism and Disposition, vol. 23, no. 11, pp. 1206-1214, 1995.

[10] J. L. Wiesner, A. D. de Jager, F. C. W. Sutherland et al., "Sensitive and rapid liquid chromatography-tandem mass spectrometry method for the determination of meloxicam in human plasma," Journal of Chromatography B, vol. 785, no. 1, pp. 115-121, 2003.

[11] P.-L. Toutain, N. Reymond, V. Laroute et al., "Pharmacokinetics of meloxicam in plasma and urine of horses," American Journal of Veterinary Research, vol. 65, no. 11, pp. 1542-1547, 2004.

[12] H.-K. Han and H.-K. Choi, "Improved absorption of meloxicam via salt formation with ethanolamines," European Journal of Pharmaceutics and Biopharmaceutics, vol. 65, no. 1, pp. 99-103, 2007.

[13] B. Dasandi, H. Saroj, and K. M. Bhat, "LC determination and pharmacokinetics of meloxicam," Journal of Pharmaceutical and Biomedical Analysis, vol. 28, no. 5, pp. 999-1004, 2002.

[14] H. Modesto Rigato, G. Duarte Mendes, N. Carter do Carmo Borges, and R. A. Moreno, "Meloxicam determination in human plasma by high-performance liquid chromatography coupled with tandem mass spectrometry (LC-MS-MS) in Brazilian bioequivalence studies," International Journal of Clinical Pharmacology and Therapeutics, vol. 44, no. 10, pp. 489-498, 2006.

[15] W. R. G. Baeyens, G. van der Weken, E. D’haeninck et al., "Application of an alkyl-diol silica precolumn in a column-switching system for the determination of meloxicam in plasma," Journal of Pharmaceutical and Biomedical Analysis, vol. 32, no. 4-5, pp. 839-846, 2003.

[16] K. Baert and P. de Backer, "Disposition of sodium salicylate, flunixin and meloxicam after intravenous administration in broiler chickens," Journal of Veterinary Pharmacology and Therapeutics, vol. 25, no. 6, pp. 449-453, 2002.

[17] J. A. Palma-Aguirre, M. Lopez-Gamboa, L. Cariño, V. BurkeFraga, and M. González-de la Parra, "Relative bioavailability of two oral formulations of piroxicam $20 \mathrm{mg}$ : a single-dose, randomized-sequence, open-label, two-period crossover comparison in healthy Mexican adult volunteers," Clinical Therapeutics, vol. 32, no. 2, pp. 357-364, 2010.

[18] L. Edno, F. Bressolle, B. Combe, and M. Galtier, "A reproducible and rapid HPLC assay for quantitation of piroxicam in plasma," Journal of Pharmaceutical and Biomedical Analysis, vol. 13, no. 6, pp. 785-789, 1995.

[19] M. T. Maya, J. P. Pais, and J. Morais, "A rapid method for the determination of piroxicam in plasma by high-performance liquid chromatography," Journal of Pharmaceutical and Biomedical Analysis, vol. 13, no. 3, pp. 319-322, 1995. 

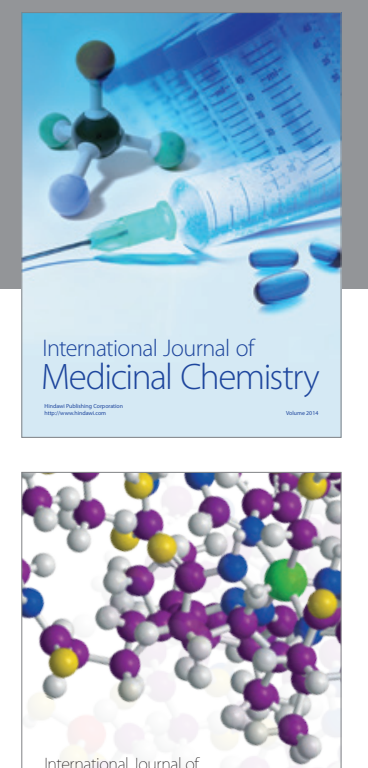

\section{Carbohydrate} Chemistry

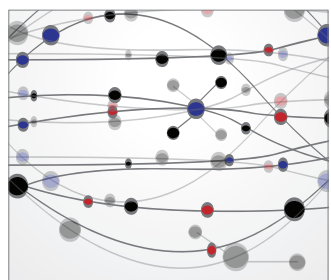

The Scientific World Journal
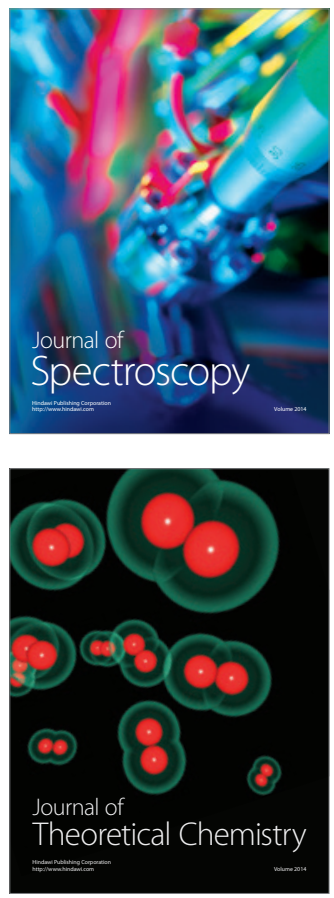
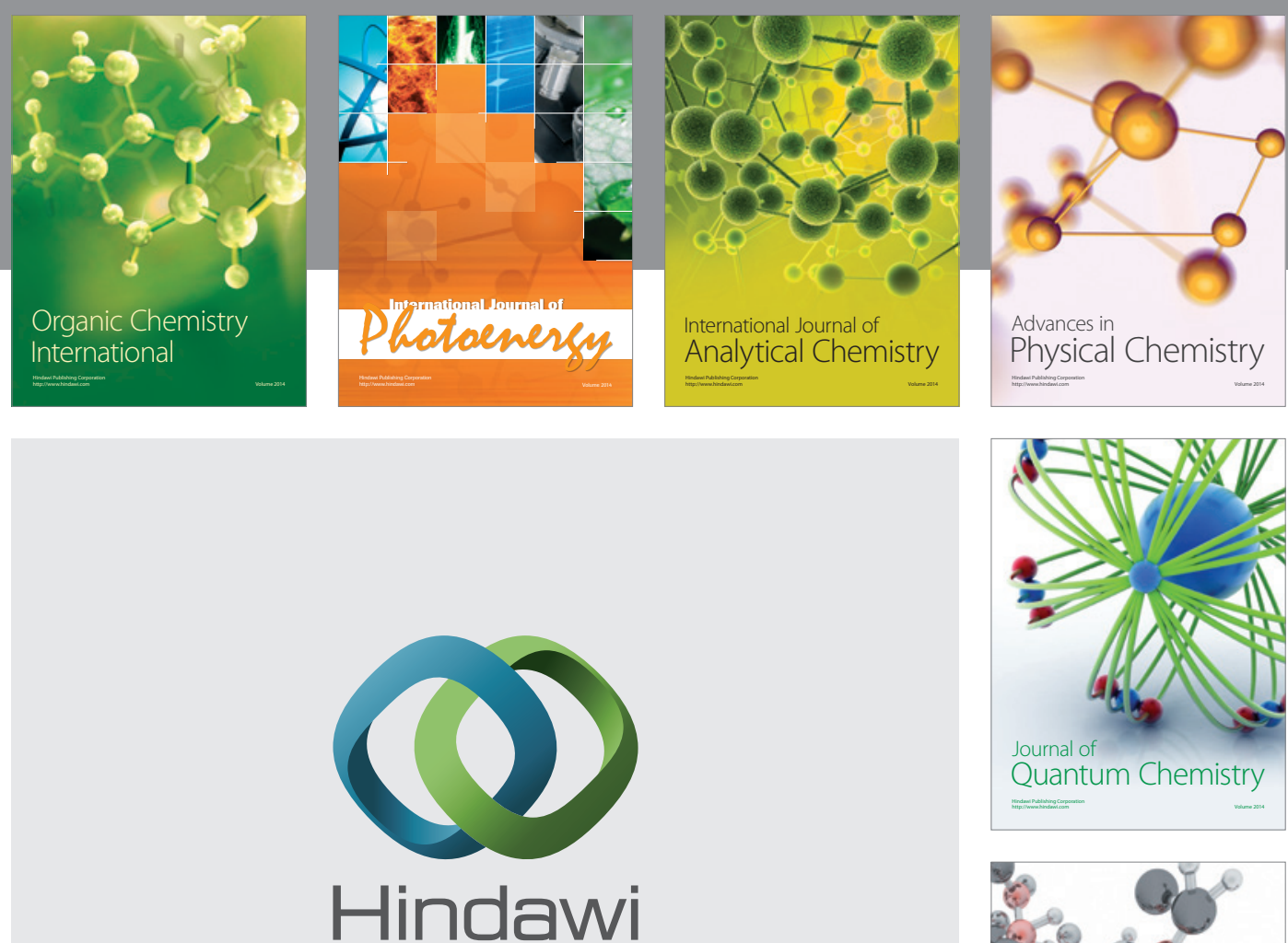

Submit your manuscripts at

http://www.hindawi.com

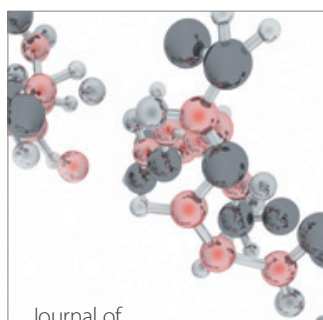

Analytical Methods

in Chemistry

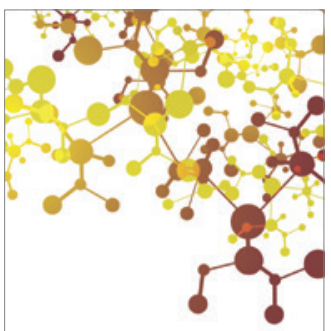

Journal of

Applied Chemistry

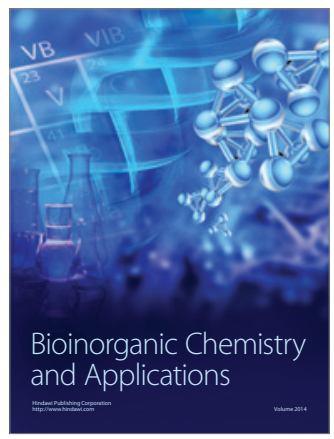

Inorganic Chemistry
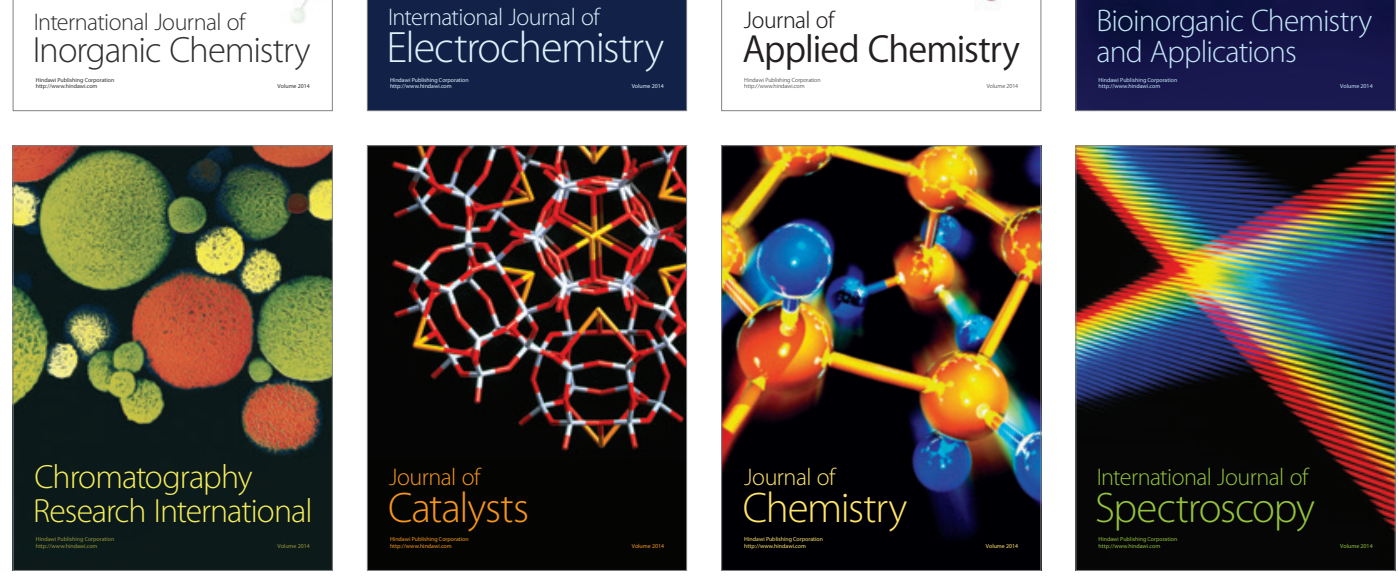